\author{
Merlin Donald
}

\title{
Z punktu widzenia literatury ${ }^{1}$
}

Eksplorując dziedziny etologii klinicznej i obserwacji naturalnej, musimy również mieć na względzie ich najwyżej rozwinięte (tzn. celowe i świadome) przejawy. Wielkim luksusem - którego nie są w stanie dostarczyć nam kliniczne studia nad świadomością, gdyż nawet najbardziej doświadczeni klinicyści pozostają na zewnątrz umysłów pacjentów, są też ograniczani formalną, konwencjonalną naturą swych kontaktów z innymi - staje się wówczas badanie literatury pięknej. Fikcja literacka nie zna podobnych ograniczeń. Jest w całości wytworem imaginacji, zatem pisarze nie są tak spętani konwencją. Ich perspektywa daje inny rodzaj konfrontacji z rzeczywistością, również opartej na obserwacji eksperckiej, lecz prowadzonej od wewnątrz. Literatura to bodaj najwyższa artykulacja ludzkiego doświadczenia, jaką posiadamy, i choćby tylko z tego względu należy ją umieścić w naszej bazie danych.

Najwybitniejsi twórcy literatury rozszerzyli subiektywne badanie umysłu ludzkiego daleko poza granice dopuszczalne

1 Szkic jest rozdziałem z książki A Mind So Rare. The Evolution of Human Consciousness [Donald 2001] [przyp. red.]. 
w psychologii klinicznej czy eksperymentalnej. Zawsze posiadają oni bowiem - bez względu na to, czy się do tego przyznają, czy nie - jakąś implicytną wiedzę psychologiczną, odzwierciedlającą sposób, w jaki dana kultura pojmuje kondycję ludzką, w tym kondycję samej psyche oraz świadomości. Nasze najgłębiej ukryte założenia dotyczące tej ostatniej szczególnie często eksplorują powieściopisarze. Ich portrety ludzkiej świadomości składają się na przeogromną, nieuporządkowaną w sposób systemowy kolekcję zjawisk obserwowanych od wewnątrz i, jak się zdaje, najbardziej miarodajnie opisanych. Czym jest zatem fenomenologia świadomości prezentowana w literaturze? Trudno to w prosty sposób podsumować. Jednak jeśli chodzi o pytanie główne, dotyczące tego, czy świadomy umysł jest aktywny czy pasywny, literatura, ogólnie rzecz biorąc, okazuje się bliższa poglądom klinicystów niż ortodoksyjnych psychologów [Hardliners].

Pomijając kilka istotnych wyjątków, literatura zaczęła zgłębiać świadomość dopiero jakieś dwieście lat temu. Większość narracji powieściowych prowadzona jest albo w pierwszej osobie, przez postacie, których strumień świadomości zostaje udostępniony odbiorcom, lub trzecioosobowo, przez narratora rozwijającego w swojej świadomości daną historię. Powieściopisarze, którzy szczegółowo badają wewnętrzne życie umysłu, wierzą w ogromną władzę świadomości. Fragment z Bostończyków Henry’ego Jamesa dobrze pokazuje, jak w kręgach społecznych tego autora wyobrażano sobie subtelności indywidualnej świadomości. W poniższym akapicie James opisuje dylematy rozgrywające się w umyśle głównej bohaterki:

Olive uświadomiła to sobie dotkliwie podczas wizyty w jego mieszkaniu: był tak wesoły, serdeczny i uważny, tak uprzejmy wobec panny Chancellor oraz z taką lekkością i wdziękiem pełnił honory gospodarza, że przez większość czasu siedziała jak zaklęta, potrząsając sumieniem jak zepsutym zegarkiem, aby podsunęło jej lepszy powód antypatii. Niechęć do jego matki nie przysporzyła jej większych problemów, ale z grubsza mijała się z celem. Pani Burrage przyjechała na parę dni do syna; zatrzymała się w hotelu. Olive wiedziała, że grzecznie 
byłoby ją tam odwiedzić, odstąpiła jednak od tego pomysłu pod pretekstem bostońskiego temperamentu, który na ogól uchodził płazem w oczach przyjezdnych. Pani Burrage roztaczała wprawdzie aurę osoby, która nie zwróci uwagi na tak błahy afront, lecz Olive czerpała pewną przyjemność $\mathrm{z}$ faktu, iż nawet najmniejsza zemsta ma słodki smak. [James 2014: 192-193]

We fragmencie tym dzieje się znacznie więcej, a zacytowana scena to tylko drobna cząstka dużo dłuższego epizodu. Olive Chancellor to wspaniała, choć nieco zmarginalizowana bohaterka, której świadomy umysł nieustannie snuje towarzyskie intrygi i knowania. James pokazuje nam, jak w mgnieniu oka i bez najmniejszego wysiłku potrafi ona ocenić nader subtelną sytuację międzyludzką. Olive doskonale zdaje sobie sprawę z własnych motywów, szybko potrafi też rozpoznać pobudki kierujące panią Burrage i uświadamia sobie, że oboje, matka oraz syn, lecz zwłaszcza matka, będą przeszkodą w realizacji jej planów. Poddaje refleksji własne emocje, a zdając sobie sprawę, że nie jest dobrą aktorką, rozumie, iż - by zrealizować swoje zamiary - musi wzbudzić w sobie autentyczną antypatię w stosunku do pani Burrage (podobnie jak Zasecki ${ }^{2}$ kombinuje, co zrobić, ażeby to, co stanowi jej słabość, nie stało się przeszkodą w realizacji ściśle wykalkulowanego celu). Póki co postanawia zwieść Burrage’ów. Wszystko to rozgrywa się w umyśle Olive błyskawicznie, podczas gdy na zewnątrz zachowuje się ona najzupełniej poprawnie z punktu widzenia społecznie akceptowalnych manier. Jej zachowanie nie jest jednak spontaniczne, ale obliczone na zmylenie przeciwnika.

Taki obraz świadomej pracy umysłu okazuje się niekompatybilny z twierdzeniem ortodoksyjnych psychologów, iż świadomość jest, generalnie rzecz biorąc, pasywna i nieefektywna. Świadome centrum Olive jest niezwykle zapracowane i spójne.

Lew Aleksandrowicz Zasecki - pacjent rosyjskiego neuropsychologa Aleksandra Lurii. Podczas bitwy pod Smoleńskiem (1943) został on ciężko ranny w głowę i wskutek uszkodzeń mózgu stracił umiejętność czytania, pisania, a także, do pewnego stopnia, mówienia, miał również zaburzenia pamięci i wzroku [przyp. thum.]. 
Jej umysł dokonuje dogłębnej, symultanicznej oraz rozważnej oceny każdego z trojga bohaterów uczestniczących w scenie, a to wymaga znacznej umiejętności błyskawicznego oszacowywania cudzych stanów umysłu na podstawie znikomej liczby sygnałów. Pojawiające się w jej świadomości refleksje na temat oczekiwań Burrage’ów powodują, że Olive, chcąc wywrzeć na nich określone wrażenie, zaczyna działać w sposób bardzo wyrachowany. Ma również świadomość, że tłumi w sobie nieprzepartą chęć zupełnie innego zachowania i że zataja oraz bezwzględnie kontroluje swe prawdziwe emocje (poczucie winy, ekscytację, resentyment, frustrację i wyczekiwanie). Jednocześnie snuje plany na przyszłość i rejestruje najróżniejsze szczegóły zachowania pani Burrage (to ona stanowi dla niej prawdziwe zagrożenie, gdyż większość mężczyzn to zdaniem Olive prostacy, którzy nie są w stanie stawić czoła jej własnym kompetencjom społecznym). W dodatku Olive wykonuje owe czynności umysłowe, nie zdradzając się ani słowem, i równolegle uczestniczy w toczącej się w salonie własnym torem konwersacji, która sama w sobie jest skomplikowaną grą społeczną, jako że pani Burrage dorównuje Olive w sztuce manipulowania ludźmi i pod powierzchnią rozmowy układa własną intrygę.

Mistrzostwo Jamesa w tworzeniu podobnych scen wzbogaca nasze rozważania o zarządzaniu sferą interakcji przez świadomość, dodając do nich czynnik, któremu psychologowie eksperymentalni poświęcili rozległe studia. Czynnik ten określa się mianem wielozadaniowości [multitasking], czyli zdolności wykonywania lub rozważania w myślach wielu rzeczy naraz. Omawiając zagadnienie gier i konwersacji, mogliśmy się przekonać, że gatunek ludzki ma do tego wyjątkowe predyspozycje. Badania laboratoryjne wykazały, iż większość osób może wykonywać jednocześnie dwa, a czasem nawet trzy zadania, na przykład zapamiętywać serie wyrazów w trakcie gry wideo. Podobne sytuacje wzięte z codziennego życia to choćby prowadzenie rozmowy z pasażerem podczas prowadzenia samochodu czy mieszanie sałaty i słuchanie wiadomości telewizyjnych. Są to dobre przykłady, lecz w żaden sposób nie testują granic naszej wielozadaniowości. A James to właśnie czyni. 
Świat Jamesowskiej prozy dostarcza bardziej realistycznych obrazów naszych niezwykłych uzdolnień do uprawiania wielozadaniowości w sferze społecznej, gdyż pisarz ów sięga głęboko pod powierzchnię zjawisk. Obiektywne zachowania, które mógłby zaobserwować ktoś z zewnątrz w trakcie wymiany zdań między Olive i Burrage'ami, dałyby tylko spłycone wrażenie tego, co się dzieje. Ich zachowanie to tylko pierwsza warstwa znacznie głębszych procesów kognitywnych i odzwierciedla jedynie faktyczne działania oraz słowa uczestników rozmowy. Jednak narracja Jamesowska pokazuje, iż umysły generujące i regulujące owe fasadowe działania są znacznie bardziej zaprzątnięte roztrząsaniem długoterminowych kwestii strategicznych. Postacie w jego powieściach mogą się rozmaicie zachowywać, zazwyczaj w celu wywołania określonego wrażenia, ale w istocie szukają słabych punktów we wrogim obozie, uprawiają dość bezwzględny samokrytycyzm i prognozują przyszłe efekty swoich działań.

Olive Chancellor - postać fikcyjna - potrafi przetwarzać w świadomości mnóstwo spraw jednocześnie i, jak widzimy, każdą z nich odrębnie zajmować się i oceniać. Przy tym ani na chwilę nie traci orientacji, kim jest, zachowuje poczucie własnej wartości, doskonale zdaje sobie sprawę, dlaczego znalazła się w tym właśnie miejscu i jak obecna sytuacja może wpasować się w szerzej zakrojoną intrygę. Pisarskie obserwacje możemy zweryfikować, porównując je z własnym doświadczeniem, i znaleźć konsensus, który pod względem formalnym nie będzie się różnił od, dajmy na to, optycznego efektu pasm Macha ${ }^{3}$. Wszyscy znamy ten rodzaj doświadczeń polegających na wielopoziomowym zarządzaniu własnym zachowaniem. Jest niemal pewne, że przedstawiciele gatunku ludzkiego stale doświadczają takich złożonych procesów zachodzących w świadomości. O ile wiem, żaden wyrafinowany krytyk nie zakwestionował nigdy psychologicznych teorii wpisanych implicite w powieści Jamesa. Nawet jego własny brat, William James, jeden z wybitnych teoretyków psychologii w swoim pokoleniu - jak się zdaje - nie miał do nich zastrzeżeń.

3 Efekt pasm Macha - odkryta w 1865 roku przez Ernsta Macha właściwość percepcji wzrokowej, rodzaj złudzenia optycznego, które objawia się widzeniem nieistniejących pasm i zmian jasności sąsiednich obszarów [przyp. tłum.]. 
Kolejne drobne spostrzeżenie w związku prozą Jamesa może nam rzucić światło na inny element doświadczeń świadomościowych. Wcześniej pisałem o tym, jak ważna jest zawartość pamięci służącej jako tymczasowy rezerwuar dla wspomnień, które $\mathrm{w}$ danym momencie są szczególnie przydatne, wręcz kluczowe. Zazwyczaj bada się działanie pamięci w warunkach laboratoryjnych, za pomocą prostych testów, na przykład prosząc badanych o powtórzenie wielocyfrowych liczb lub o zapamiętanie położenia różnych obiektów ukrytych na obrazku. W takich testach świadomość bohaterki Bostończyków okazałaby się zapewne bardzo podobna do naszej własnej. Przypuszczalnie Olive byłaby w stanie powtórzyć pięć do sześciu cyfr w podanej liczbie i zapamiętać pięć do sześciu elementów z obrazka. Jednak James implicite twierdzi, że w sztuce rozpoznawania tego, co dzieje się między ludźmi, jej pamięć jest iście gargantuiczna. Proza Jamesa obala znane twierdzenie George’a Millera, że limit wykonywanych jednocześnie przez świadomość zadań wynosi $7 \pm 2$. Czyni tak dzięki temu, że pisarz ów nie zajmował się senso-motorycznym interfejsem, lecz eksplorował wewnętrzną przestrzeń psychiki. W kontekście świadomej samoregulacji pamięć Olive ewidentnie sięga w przeszłość znacznie dalej niż tylko owe piętnaście sekund, które się człowiekowi zwykle przypisuje. Bohaterka potrafi w mgnieniu oka przypomnieć sobie konkretne słowa, gesty i oznaki, które zaistniały na wiele minut czy godzin wcześniej, nawet jeśli w danym momencie nie wydawały się znaczące. Jest też w stanie wyobrażać sobie hipotetyczne konwersacje czy wymiany zdań na piśmie, a także brać pod uwagę w swych roztrząsaniach szczegółowe wyrażenia, nieme spojrzenia, subtelne zmiany postaw oraz całe mnóstwo innych bezsłownych symptomów zdradzających prawdziwe intencje innych osób czy grup ludzi. Jak dowodzą zgodne reakcje wykształconych, krytycznych i zdolnych do introspekcji czytelników powieści, to wszystko, co potrafi zdziałać świadomość Olive, umiemy zrobić i my.

Henry James pokazał, że świadomość Olive w każdym momencie jest niesłychanie rozległa, rozciąga się w czasie i przestrzeni, a także w bardziej abstrakcyjnych obszarach geografii społecznej. Bohaterka przypomina wybitną szachistkę pochyloną nad 
ogromnych rozmiarów szachownicą. Rozważa możliwe posunięcia własne, a jednocześnie analizuje ( $\mathrm{z}$ niechętnym podziwem) błyskotliwe ruchy przeciwników. Ani przez chwilę nie traci czujności i uwagi. Co więcej, zachowując w świadomości ogólny obraz swego życia, nieustannie, perfekcyjnie i bez najmniejszego wysiłku wykonuje wszystkie drobniejsze funkcje kognitywne, przerzucając odpowiedzialność za nie na swych automatycznych służących, których trzyma na krótkiej smyczy. Właśnie te funkcje, dla ludzi dorosłych tak proste, iż do ich wykonywania rzadko trzeba uruchamiać zasoby samoświadomości, na nieszczęście dla psychologów eksperymentalnych do znudzenia bada się w laboratoriach, ponieważ są najłatwiej mierzalne. Olive z największą łatwością robi rzeczy tak przyziemne, jak percypowanie różnych obiektów, wynajdywanie odpowiednich słów, budowanie poprawnych gramatycznie zdań, skupianie i przenoszenie uwagi, poruszanie się w trójwymiarowej przestrzeni, koordynowanie ruchów dłoni i gałek ocznych, czytanie na głos oraz wiele innych. Często wykonuje symultanicznie kilka z tych operacji - utrzymuje w równowadze filiżankę i miesza łyżeczką cukier w herbacie, nie roniąc przy tym ani kropli płynu, a przy okazji przechadza się po pokoju, wygląda przez okno i planuje następne posunięcia w swojej intrydze. Wszystko to dzieje się niemal bez nadzoru świadomości, gdyż na poziomie świadomym umysł jej zaprzątnięty jest rozwijającą się, nader skomplikowaną grą międzyludzką. Cała ta złożoność sytuacji w niczym nie zraża umysłu Olive, który pozostaje w pełni skoncentrowany i sprawny. Natomiast jej świadomość jest pochłonięta tym, co w danej chwili najważniejsze: planowaniem wojny z Burrage’ami.

Ów stworzony przez pisarza krystalicznie przejrzysty obraz pracy umysłu całkiem nieźle współgra z wieloma przypadkami klinicznymi odnotowanymi w literaturze neuropsychologicznej. Daje wyobrażenie o złożoności, którą na co dzień zarządza ludzki umysł, i pozwala lepiej pojąć ogrom abstrakcji, z jakim w swych rutynowych operacjach ma do czynienia nasza świadomość. Przypomina nam również, jak wielka jest skala problemu. Z tej perspektywy obsesja ortodoksyjnych psychologów na tle pamięci krótkotrwałej i automatycznej natury wielu naszych czynności senso-motorycznych to, jak się zdaje, totalne nieporozumienie. 
Owszem, część ich twierdzeń jest prawdziwa, ale zatrważająco niekompletna, w dodatku kieruje naszą uwagę nie tam, gdzie trzeba. Świadoma praca umysłu Olive Chancellor to nie pasywny wir wrażeń. Nie można jej dobrze zmierzyć, rejestrując tylko to, co Olive widzi, lub obserwując, jak wykonuje proste zadania.

Na płaszczyźnie sytuacji towarzyskich świadomość Olive jest aktywna, wręcz hiperaktywna, aż do granic agresywności. Bohaterka nieustannie snuje plany i niezmordowanie dokonuje autokorekty, przypominając pod tym względem Zaseckiego. Jednak w odróżnieniu od tego nieszczęśnika o całkowicie zrujnowanym aparacie percepcyjnym, wielowarstwowa samoświadomość Olive gładko scala różne pod względem modalnym wrażenia oraz poziomy abstrakcji. Tego rodzaju jedność potrafi ogarnąć wielkie połacie czasu i z wielu długotrwałych epizodów utkać pamięciową materię życia. A życie, które nigdy nie doświadcza zerwania ciągłości, nigdy też nie traci poczucia własnego ja, poczucia własnego miejsca, czasu i celu.

Choćby nasze stulecie nie wiem jak nas zblazowało, nie powinniśmy ustawać w zachwycie nad cudem świadomego umysłu. Ani Olive, ani nas wszystkich w ogóle nie obchodzą rzekome ograniczenia i ułomności naszej psyche. Świadomość Jamesowskiej bohaterki z naddatkiem potrafi sprostać zadaniu, które przed nią stoi. Olive jest pewna siebie i pełną parą sunie przez życie, jak to czyni większość z nas. Po każdym epizodzie przechodzi do kolejnych, niekiedy wycofując się do swych apartamentów, gdzie może kontemplować zwycięstwa i porażki oraz obmyślać taktykę na przyszłość. Oto zupełnie inna koncepcja świadomości - bezproblemowej, zintegrowanej i dążącej do jeszcze większej integracji, pewnej siebie i doskonale wszystkim zawiadującej. 


\section{Bibliografia}

Donald Merlin (2001), A Literary View, w: tegoż, A Mind So Rare.

The Evolution of Human Consciousness, Norton, Nowy Jork [USA], s. $78-83$.

James Henry (2014), Bostończycy, przeł. Magdalena Moltzan-Małkowska, Prószyński - S-ka, Warszawa.

\section{Merlin Donald}

\section{A Literary View}

Based on the analysis of a fragment of Henry James's novel The Bostonians, the article deals with the ways in which literary fiction explores and reveals how human consciousness works.

Keywords: mind; consciousness; novel; multitasking; Henry James.

Merlin Donald - emerytowany profesor Uniwersytetu Queen's w Kingston (Kanada); od 2005 roku profesor i założyciel Katedry Nauk Kognitywnych na Uniwersytecie Case Western Reserve w Cleveland (USA). Neuropsycho$\log$ z wykształceniem filozoficznym. Autor wielu prac naukowych, między innymi książek Origins of the Modern Mind. Three Stages in the Evolution of Culture and Cognition [Poczatki nowoczesnego umystu. Trzy etapy ewolucji kultury i poznania] (1991) oraz A Mind So Rare. The Evolution of Human Consciousness [Niezwykły umysł. Ewolucja ludzkiej świadomości] (2001), w których dowodzi, że na drodze ewolucji umysł pozyskał nową strategię poznawczą, stąd ważne w jego rozwoju jest „zanurzenie” mózgu w świecie, w rozproszonej sieci komunikacyjnej, funkcjonowanie w złożonej kulturze symbolicznej.

Ewa Kraskowska - prof. dr hab., kierowniczka Zakładu Literatury xx Wieku, Teorii Literatury i Sztuki Przekładu w Instytucie Filologii Polskiej Uniwersytetu im. Adama Mickiewicza w Poznaniu. Specjalizuje się w badaniach nad pisarstwem kobiet oraz w studiach nad przekładem. 
